\title{
PENGARUH SEDUHAN TEH DAUN BANGUN-BANGUN TERHADAP PRODUKSI ASI DI DESA SELAYANG WILAYAH KERJA PUSKESMAS SELESAI KECAMATAN SELESAI KABUPATEN LANGKAT TAHUN 2018
}

\author{
Betty Mangkuji, Yusniar Siregar, Bebi Lovita \\ Jurusan Kebidanan, Politeknik Kesehatan Kemenkes RI Medan
}

\begin{abstract}
Abstrak
Air susu ibu (ASI) adalah sebuah cairan tanpa tanding ciptaan Allah untuk memenuhi kebutuhan gizi bayi dan melindunginya melawan kemungkinan serangan penyakit. Produksi ASI dipengaruhi oleh dua hormone, yaitu prolaktin dan oksitosin serta laktogagum dalam bahan makanan mampu meningkatkan produksi ASI sehingga daun bangun-bangun cocok untuk peningkatan ASI karena mengandung laktogagum.Tujuan penelitian: Mengetahui pengaruh daun bangun-bangun terhadap peningkatan produksi ASI pada ibu menyusui di Desa Selayang Wilayah Kerja Puskesmas Selesai Kecamatan Selesai Kabupaten Langkat. Metodologi penelitian yaitu menggunakan desain penelitian Quasi Experiment Design dengan menggunakan pendekatan Non-Equevalent Control Group. Penelitian ini melihat bagaimana pengaruh pemberian seduhan teh daun bangun-bangun terhadap produksi ASI pada ibu menyusui dengan jumlah sampel 20 orang.Hasil Penelitian: Pada hasil penelitian ini didapatkan $p$ value $=0,000$ ( $\mathrm{p}$ value $<0,05$ ) berarti Ho ditolak, yang artinya Ada pengaruhdaunbangun-bangun terhadap produksi ASI di desa SelayangWilayah KerjaPuskesmas Selesai Kecamatan Selesai Kabupaten Langkat tahun 2018.Kesimpulan : Diharapkan agar institusi dapat memfasilitasi pengembangan penelitian dengan menambah sumber-sumber buku dan menjalin kerjasama dengan instansi terkait dan pada peneliti selanjutnya diharapkan dapat mengembangkan penelitian ini dengan menggunakan daun bangun-bangun sebagai obat herbal untuk menyembuhkan penyakit lainnya.
\end{abstract}

Kata kunci : Daun Bangun-bangun, Produksi ASI

\section{PENDAHULUAN}

Menyusui merupakan sebuah proses terindah dan sangat besar manfaatnya, peneliti medis telah membuktikan bahwa ASI memiliki berbagai keunggulan yang tidak tergantikan dengan susu mana pun. Bahkan agama menekankan pentingnya memberi ASI pada buah hati bahkan Allah SWT dalam surat cintanya telah berfirman: Para ibu hendaklah menyusukan anak-anaknya selama 2 tahun penuh, yaitu bagi yang ingin meyempurnakan penyusuan. (QS AlBaqarah [2]:223).

Adanya faktor protektif dan nutrien yang sesuai dalam kandungan ASI menjamin status gizi bayi baik serta kesakitan dan kematian anak menurun. Beberapa penelitian epidemiologis menyatakan bahwa ASI melindungi bayi dan anak dari penyakit infeksi, misalnya diare, otitis media, dan infeksi pernafasan akut bagian bawah. Kolostrum mengandung zat kekebalan 10-17 kali lebih banyak dari susu matang (matur) (Kemenkes, 2014).

Dalam rangka menurunkan angka kesakitan dan kematian anak. United Nation Childrens Fund (UNICEF) dan World Health Organization (WHO) merekomendasikan sabaiknya anak hanya disusui ASI selama paling sedikit enam bulan. Pemberian ASI
Eksklusif merupakan pemberian ASI dengan tidak memberi bayi makanan atau minuman lain, termasuk air putih, selain menyusui ASI (Kecuali obat-obatan dan vitamin atau mineral tetes, ASI perah juga diperbolehkan) (Kemenkes, 2014).

Berdasarkan Profil Kesehatan Indonesia (2015) Persentase bayi 0-5 bulan yang masih mendapat ASI eksklusif sebesar 54,0\%, sedangkan bayi yang telah mendapatkan ASI eksklusif sampai usia enam bulan adalah sebesar 29,5\%. Mengacu pada target Renstra tahun 2016 yang sebesar 42\%, namun secara nasional cakupan pemberian ASI eksklusif sebesar 80\%. Melihat hal ini pemberian ASI eksklusif belum memenuhi target nasional. Di Sumatera Utara untuk pemberian ASI Eksklusif sudah mencapai target yaitu sebesar 46,8\% dari target Renstra 42\% namun belum memenuhi target nasional.

Dalam Jurnal Iwansyah (2017) mengatakan bahwa Air Susu Ibu (ASI) memiliki peranan penting dalam pertumbuhan dan perkembangan anak, terutama di periode sensitif ( $0-24$ bulan). Keterbatasaan produksi ASI yang tidak mencukupi menjadi alasan yang sering dilaporkan oleh ibu pada masa awal menyusui. Penggunaan senyawa galaktagogum yang berasal dari tanaman merupakan salah satu upaya yang dilakukan dalam mengatasi hal tersebut. Daun bangun-bangu 
(Coleus Amboinicus L), secara empiris telah diketahui bermanfaat untuk meningkatkan produksi ASI. Beberapa penelitian telah membuktikan kebenaran khasia daun Torbangun sebagai pelancar ASI.

\section{METODE}

\section{Desain, Tempat, dan Waktu}

Desain penelitian Quasi Experiment Design dengan menggunakan pendekatan Non-Equevalent Control Group. Tempat penelitian ini adalah di Desa Selayang Kecamatan Selesai Kabupaten Langkat.Waktu penelitian sudah dilakukan pada bulan awal bulan Juli

\section{Bahan dan Alat}

Bahan dan alat yang digunakan adalah sebuuah timbangan bayi dan lembar oobservasi untuk melihat penambahan berat badan bayi pada ibu yang diberikan daun bangun-bangun dan ibu yang tidak diberikan daun bangun-bangun.

\section{Prosedur Penelitian}

Meminta surat izin dari pengelola program studi D-IV Kebidanan Politeknik Kesehatan Kemenkes Medan sebagai bukti izin melakukan penelitian. Kemudian. mengajukan surat permohonan untuk melakukan penelitian kepada Puskesmas Selesai Kecamatan Selesai Kabupaten Langkat di desa Selayang sebagai tempat penelitian kemudian menemui calon responden, memperkenalkan diri dan menanyakan apakah calon responden bersedia untuk dijadikan objek penelitian, jika setuju berikan informed consent. Setelah itu berikan produk teh daun bangunbangun kepada responden, dan beritahu cara pengkonsumsiannya secara jelas. Selama proses penelitian, akan dilakukan follow up dalam pengkonsumsian seduhan teh daun bangun-bangun selama 2 minggu serta melihat perkembangan produksi ASI ibu dengan cara melihat berat badan bayi. Setelah semua data terkumpul, peneliti melakukan pengolahan data dan analisis data.

\section{Pengolahan dan Analisa Data}

Data hasil eksperimen ditampilkan se-bagai rata-rata \pm standar deviasi (SD) dari pe-ngukuran. Data diuji normalitas dan uji homogenitas, dilanjutkan dengan uji t-independent untuk melihat perbedaan antar tiap perlakuan. Data dianalisis menggu-nakan software pengolah data SPSS.

\section{HASIL DAN PEMBAHASAN}

Berdasarkan Tabel dapat dijelaskan bahwa hasil pengukuran berat badan bayi responden yang diberikan perlakuan daun bangun-bangun diperoleh nilai rata-rata pengukuran berat badan 400 dan nilai rata-rata pengukuran berat badan responden tanpa diberi daun bangun-bangun 180 .
Berdasarkan tabel terjadi perubahan nilai ratarata pengukuran berat badan bayi sebagai indikator produksi ASI diberi dan tidak diberikan daun bangunbangun yaitu 180 menjadi 400 dengan nilai $p=0,000<0,05$, maka dapat disimpulkan bahwa Ada pengaruh daun bangun-bangun terhadap produksi ASI di Desa Selayang Wilayah Kerja Puskesmas Selesai Kecamatan Selesai Kabupaten Langkat tahun 2018.

\section{Pengukuran N Mean $P$ Produksi ASI}

\begin{tabular}{llll}
\hline $\begin{array}{l}\text { Diberi daun } \\
\text { bangun bangun }\end{array}$ & 10 & 400 & \\
\hline $\begin{array}{l}\text { Tidak diberi daun } \\
\text { bangun-bangun }\end{array}$ & 10 & 180 & \\
\hline
\end{tabular}

Hasil pengukuran berat badan bayi responden yang diberikan perlakuan daun bangun-bangun diperoleh nilai rata-rata pengukuran berat badan 400 dan nilai rata-rata pengukuran berat badan responden tanpa diberi daun bangun-bangun 180. Terjadi perubahan nilai rata-rata pengukuran berat badan bayi sebagai indikator produksi ASI diberi dan tidak diberikan daun bangun-bangun yaitu 180 menjadi 400 dengan nilai $p=0,000<0,05$, maka dapat disimpulkan bahwa Ada pengaruh daun bangun-bangun terhadap produksi ASI di Desa Selayang Wilayah Kerja Puskesmas Selesai Kecamatan Selesai Kabupaten Langkat tahun 2018.

Komposisi kandungan kimia daun Bangunbangun secara ilmiah belum banyak diketahui. Beberapa yang sudah pernah diteliti oleh Dr Boorsma (Heyne, 1987; Anonim, 1989), juga menurut Mardisiswojo dan Rajakmangunsudarso (1985) ditemukan bahwa dalam daun ini mengandung minyak atsiri $(0,043 \%$ pada daun segar atau $0,2 \%$ pada daun kering). Minyak atsiri dari daun Bangun-bangun selain berdaya antiseptika ternyata juga mempunyai aktivitas tinggi melawan infeksi cacing (Vasquez et al., 2000). Phytochemical database (Duke, 2000) melaporkan bahwa dalam daun ini terdapat juga kandungan vitamin C, vitamin B1, vitamin B12, beta karotin, niasin, karvakrol, kalsium, asam-asam lemak, asam oksalat, dan serat. Senyawa-senyawa tersebut berpotensi terhadap bermacam-macam aktivitas biologik, misalnya antioksidan, diuretik, analgesik, mencegah kanker, antitumor, antivertigo, immunostimulan, antiradang, antiinfertilitas, hipokolesterolemik, hipotensif, serta memiliki kandungan laktogagum yang berfungsi meningkatkan laju sekresi dan peningkatan produksi ASI (Santoso,2005).

Menurut asumsi peneliti dengan kandungan yang terdapat pada daun bangun-bangun dapat meningkatkan produksi ASI ibu sehingga memberikan dampak baik terhadap pertumbuhan bayi. Tumbuhan bangun-bangun sangat gampang tumbuh dimana saja namun jarang ditemukan dipekotaan dan biasanya banyak didaerah pemukiman orang batak. Bagi 
masyarakat yang tinggal di pedesaan, tumbuhan bangun-bangun bisa digunakan sebagai pagar pembatas kebun atau tanah mereka. Jika masyarakat memiliki sisa lahan dan bisa dipergunakan untuk tanaman obat keluarga (TOGA), tanamlah tanaman bangun-bangun sehingga sewaktu waktu dapat digunakan pengobatan alternatif.

\section{KESIMPULAN}

Berdasarkan hasil penelitian pengaruh daun bangun-bangun terhadap produksi ASI di desa Selayang wilayah Kerja Puskesmas Selesai Kecamatan Selesai Kabupaten Langkat tahun 2018 didapatkan Hasil pengukuran produksi ASI yang di beri daun bangun-bangun tidak ada yang bermasalah sebanyak 10 orang (100\%) dan yang tidak diberi daun bangunbangun yang mengalami masalah berjumlah 3 orang (30\%) dan yang tidak bermasalah berjumlah 7 orang (70\%) kemudian hasil dari penelitian ini adalah $p$ value $=0,000$ ( $\mathrm{p}$ value < 0,05) berarti Ho ditolak, yang artinya Ada pengaruh daun bangun-bangun terhadapproduksi ASI di Desa Selayang Wilayah Kerja Puskesmas Selesai Kecamatan Selesai Kabupaten Langkat tahun 2018.

\section{DAFTAR PUSTAKA}

Ari dan Adriani, feyriska Rahma.2015. Membesarkan Anak Hebat dengan ASI.Cetakan Pertama Citra Media Pustaka: Yogyakarta.

Astutik, Reni Yuli.2015.Asuhan Kebidanan Masa Nifas dan Menyusui.Cetakan Pertama.CV.Trans Info Media: Jakarta Timur.

Iwansyah, Ade Chandra, dkk.2017. Potensi Fraksi Etil Asetat Daun Torbangun (Coleus amboinicus L.) Dalam Meningkatkan Produksi Susu, Bobot Badan IInduk, dan Anak Tikus. Jurnal Gizi Pangan. 12(1):61-6
Kementerian Kesehatan RI. 2014. Profil Kesehatan Indonesia

014.http://www.depkes.go.id/resources/downloa d/pusdatin/profilkesehatan-

indonesia/profilkesehatan-Indonesia-2014.pdf (diunduh 16 Februari 2018).

\section{Indonesia}

2015. Profil Kesehatan

2015.http://www.depkes.go.id/resources/downlo ad/pusdatin/profilkesehatanindonesia/profilkesehatan-Indonesia-2015.pdf (diunduh 16 Februari 2018).

Maritalia, Dewi.2014.Asuhan Kebidanan Nifas dan Menyusui.Cetakan Kedua. Pustaka Pelajar:Yogyakarta.

Marmi.2014.ASI Saja Mama Berikan Aku ASI Karena Aku Bukan Anak Sapi.Cetakan Pertama.Pustaka Pelajar Yoyakarta.

Marmi dan Rahardjo Kukuh.2015. Asuhan Neonatus, Bayi,Balita, dan Anak Pra Sekolah.Cetakan Ketiga. Pustaka Pelajar: Yogyakarta.

Santosa, Christin Marganingsih dan Triana Hertiani. 2005. Kandungan senyawa kimia dan efek ekstrak air Daun Bangun-bangun (Coleus amboinicus,L.) pada aktivitas fagositosis netrofil tikus putih (Rattus norvegicus. Jurnal Majalah Farmasi Indonesia. 16 (3), 141-148.

Wiji, Rizki Natia.2015.ASI dan Panduan Ibu Menyusui.Edisi Kedua.Cetakan Kedua.Nuha Medika : Yogyakarta. 